University of Nebraska - Lincoln

DigitalCommons@University of Nebraska - Lincoln

USDA National Wildlife Research Center - Staff

Publications

U.S. Department of Agriculture: Animal and Plant Health Inspection Service

July 2006

Invasive Predators: a synthesis of the past, present, and future

William C. Pitt

USDA/APHIS/WS, National Wildlife Research Center

Gary W. Witmer

USDA-APHIS-Wildlife Services, gary.w.witmer@usda.gov

Follow this and additional works at: https://digitalcommons.unl.edu/icwdm_usdanwrc

Part of the Environmental Sciences Commons

Pitt, William C. and Witmer, Gary W., "Invasive Predators: a synthesis of the past, present, and future" (2006). USDA National Wildlife Research Center - Staff Publications. 436.

https://digitalcommons.unl.edu/icwdm_usdanwrc/436

This Article is brought to you for free and open access by the U.S. Department of Agriculture: Animal and Plant Health Inspection Service at DigitalCommons@University of Nebraska - Lincoln. It has been accepted for inclusion in USDA National Wildlife Research Center - Staff Publications by an authorized administrator of DigitalCommons@University of Nebraska - Lincoln. 


\section{Invasive Predators: a synthesis of the past, present, and future}

"...if all the animals and plants of Great Britain were set free in New Zealand, a multitude of British forms would over the course of time become thoroughly naturalized there, and would exterminate many of the natives." Darwin 1872

William C. Pitt ${ }^{1}$ and Gary W. Witmer ${ }^{2}$

${ }^{1}$ USDA/APHIS/WS, National Wildlife Research Center, Hawaii Field Station, P.O. Box 10880, Hilo, Hawaii 96721; ${ }^{2}$ USDA/APHIS/WS, National Wildlife Research Center, 4101 LaPorte Avenue, Fort Collins, Colorado 80521

\subsection{Abstract}

Invasive predators have had devastating effects on species around the world and their effects are increasing. Successful invasive predators typically have a high reproductive rate, short generation times, a generalized diet, and are small or secretive. However, the probability of a successful invasion is also dependent on the qualities of the ecosystem invaded. Ecosystems with a limited assemblage of native species are the most susceptible to invasion provided that habitat and climate are favorable. In addition, the number of invasion opportunities for a species increases the likelihood that the species will successfully establish. The list of routes of entry or pathways into many ecosystems continues to grow as transportation of goods into even the remotest areas become common. Species may enter new areas accidentally (e.g., hitchhikers on products) or as intentional introductions (e.g., sport fish). Pet releases, either accidental or intentional, are a growing area of concern as exotic pets become common and the desire for new or different species grows. Several invasive predators have had major effects on prey populations around the world (e.g., black rats, feral cats, mongoose) or have had devastating effects in isolated areas (e.g., brown treesnakes, Nile perch). Although management of established species has been a priority, eradication has been extremely difficult once a species has become widely distributed. However, little resources are directed toward interdiction efforts, removing 
incipient populations, or preventing new introductions. The regulation of animal movement in most countries and the inspection of products being moved were not developed to protect native ecosystems. Thus, species may be moved with relative ease between regions and countries. The most cost effective approach to invasive species management is to prevent new species from becoming established by providing funding for interdiction efforts, research prior to a species becoming widespread, and restricting the movement of species.

Keywords: Amphibians, birds, invasive species, fish, mammals, management, predation, regulation, reptiles.

\subsection{Introduction}

Invasive species are species nonnative to a specific ecosystem that cause or may cause ecological harm, negative economic effects, or harm to human health and safety (National Invasive Species Council 2001). Although some nonnative species may be viewed as beneficial (e.g., crops), many have had dramatic effects on the ecosystems invaded. In particular, invasive predators have had catastrophic effects on numerous species during the past several hundred years (Savidge 1988; Witte et al. 1992; Vitousek et al. 1996). These effects likely will increase as more predators are moved, existing habitats are reduced, and the pressure placed on ecosystems is increased. Each new predator introduced increases the chances that additional species will be lost to extinction (Blackburn et al. 2004). This chapter is an attempt to synthesize the effects of invasive predators on terrestrial ecosystems and to present the current status and emerging trends. We have limited the chapter's coverage to invasive vertebrate predators because they are often overlooked, management may be controversial due to competing interests, and their effects are increasing worldwide (Simberloff 1996; Lockwood 1999).

In the last 200 years, many species have been decimated or reduced to extinction by invasive predators, but in the last 30 years as transportation to even the most remote location has become commonplace, the number of invasive predators has increased and their effects are increasing (Simberloff 1996; Mooney and Hobbs 2000; Long 2003). Successful invasive predators generally share several common characteristics, beyond being abundant, widespread, and tolerant of a wide range of abiotic conditions (Lockwood 1999). They typically have a high reproductive rate and short generation times so the populations can grow quickly and 
rebound from stochastic events (Lockwood 1999). They have a generalized diet to take advantage of locally abundant resources and may switch from preferred prey once prey becomes rare (Murdoch 1969). Prey switching can ultimately lead to extinction of the preferred prey because the predator population is no longer tied to the abundance of the preferred prey (Murdoch 1969). Thus, predator numbers do not decrease as the preferred prey numbers decrease because alternative prey populations support the predator population. This has been observed several times with invasive predators, such as brown treesnakes systematically eliminating the avifauna of Guam (Savidge 1987). In addition, their effects go undetected at first and they are easily transported because they are small or secretive (e.g., snakes), they are ignored by local authorities as innocuous (e.g., coqui frogs), they are purposefully moved or released (e.g., pets), commensal with humans (e.g., rats) or there is resistance to control measures (e.g., feral cats). This lack of understanding and detection allows incipient populations to become established and makes eradication difficult or impossible. Species that have all of these attributes tend to be the most successful at colonizing new habitats (Lockwood 1999).

The probability of a successful invasion is also dependent on the qualities of the ecosystem invaded (Simberloff and Von Holle 1999). Beyond a suitable climate and habitat, ecosystems with a limited assemblage of resident species are the most susceptible to invasion. The lack of resident species decreases the number of potential competitors and predators. Last but not least, the number of invasion opportunities for a species increases the likelihood that the species will successfully establish. Island ecosystems are more susceptible than mainland areas because they have few predators or competitors, they have a lot of air and sea traffic, and they typically provide a favorable climate for many species (Elton 1958, Simberloff 1995). The increased susceptibility of insular populations to extinction compared to mainland areas has been clearly delineated. Since 1600, 93 percent of the land and freshwater birds that have gone extinct worldwide were insular forms (King 1985). In addition, predation by invasive species is considered second only to habitat loss as the leading cause of avian extinctions and declines on islands, with rats (Rattus spp., $56 \%$ ) and domestic cats (Felis catus, 26\%) implicated in most avian extinctions caused by invasive predators (King 1985; Griffin et al. 1989). As remaining habitat patches mirror islands, invasive predators may have similar effects.

The number of pathways invasive species may arrive is varied and likely increasing. Generally, species are either accidentally or intentionally transported. Accidental movements include hitchhikers on agricultural products (e.g., brown treesnakes, coqui frogs) and pet escapes (e.g., 
pythons and Nile monitors). Pet escapes or releases are especially disconcerting because managers typically are not looking for species that have such a low probability of detection and released populations may remain tied to a particular location or semi-captive until the population is well established. Much of the importation of exotic wildlife is due to the enormous pet industry (Ruesink et al. 1995; Witmer and Lewis 2001). Intentional releases include those that were intended to provide food for people (e.g., feral pigs, bullfrogs), to combat other species (e.g., mongoose, feral cats, cattle egrets, cane toads), or for aesthetic or recreational reasons (e.g., sport fish, feral pigs). Although many of the intentional releases had altruistic intentions, some are for insidious or financial reasons. Species smuggled and released for the pet trade are an increasing threat and difficult to prevent because heightened security measures and the realignment of customs inspections are not focused on invasive species.

\subsection{Species profiles}

Several species have become widely publicized for their overall effect as invasive species or as successful invaders in multiple areas. Most of the highlighted species were listed as the worst invasive predators by Lowe et al. (2004) but three potentially predatory species on the list were not included because they are not that widespread or their primary effects are not from predation. Brushtail possums (Trichosurus vulpecula) do prey on invertebrates and birds but their primary effects are as a disease vector and herbivore (Clout and Ericksen 2000; Cowan 2001). The effects of common mynah are as a nuisance and agricultural pest, although they may prey and compete with native birds (Long 1981; Pell and Tideman 1997). The redeared slider (Trachemys scripta) has been introduced around the world through the pet trade. These omnivorous turtles may compete with native turtles, prey on invertebrates, forage on vegetation, and occasionally take birds (Luiselli et al. 1997; Chen and Lue 1998). We added a few species to highlight emerging issues; these include Burmese pythons, cattle egrets, barn owls, and Nile monitors. Most invasive birds are not predators but cause a myriad of agricultural and human health threats, however, these two species (barn owls and cattle egrets) were included to highlight their increasing range expansion and predation effects. Nile monitors and Burmese pythons highlight the ever increasing problem of the pet trade in establishing invasive species. The source of many of the new invasive predators are from the pet trade where people release unwanted pets or 
attempt to naturalize them so they may breed in the wild and supply demand (Ruesink et al. 1995; Cassey et al. 2004; Enge et al. 2004). In an attempt to understand the effects of invasive predators and potential problems with control efforts, we provide a brief summary of several noteworthy species and attempts at control.

\subsubsection{Mammals}

\section{Black rats}

One of the most widespread and destructive predators is the black, ship or roof rat (Rattus rattus), introduced around the world from the late 1600s to 1800s) (Long 2003). Black rats have become so ubiquitous and widespread that little attention was paid to this species, whereas new invasions receive more attention and eventually funding for research and control. Black rats are arboreal and in addition to causing significant damage to plants, black rats are efficient predators of many species, especially birds. A large majority of the recorded vertebrate extinctions since 1600 have been on islands and introduced mammals are responsible for the vast majority of these extinctions (Groombridge 1992). Further, black rats have been implicated in many of the documented extinction events, such as honeycreepers in Hawaii, United States (Atkinson 1977), small mammals in the Caribbean (Seidel and Franz 1994) land birds and a bat on Big South Cape Island, New Zealand (Atkinson 2001), and several vertebrates and invertebrates on Lord Howe Island (King 1985; Case and Bolger 1991). Rats have been the most destructive invasive species accounting for losses of numerous species around the world.

Numerous techniques have been developed to control rat populations from introducing other predators, to trapping, to fencing, to a variety of poisons. The introduction of other predators, such as mongoose, owls, or cats have had little success and usually just increased the predation pressure on native fauna. Trapping has had limited success in small areas but rats are highly mobile and may become trap shy. Fencing options for rats over large areas has not been used effectively until recently (Clapperton and Day 2001). However, fences must be combined with other techniques to initially remove rats. The most effective way to control or eradicate rats has been with the use of toxicants, primarily anticoagulants. During the last 15 years, efforts to eradicate rodents from islands have increased and many successful eradication projects have been completed using commercially available rodenticides (Myers et al. 2000; Atkinson 2001; Veitch and Clout 2002). 


\section{Feral cats}

Wild populations of domesticated cats are distributed throughout the world, wherever humans are present (Long 2003). However, in areas with reduced predator populations, feral cats often become the dominant predator and often exist at much higher densities than native predators (Van't Woudt 1990). In the United States, the feral cat population has been estimated at over 30 million and that these feral animals kill about 465 million birds per year (Pimental et al. 2000). Pimental et al. (2000) estimated the value of those birds at $\$ 17$ million. In the United Kingdom, the feral cat population may exceed 5 million and kill as many as 70 million wild animals per year (Churcher and Lawton 1987). The diet of feral and free-ranging cats varies depending on availability, abundance, and geographic location. Foods may be naturally occurring, but also include those made available by people, whether intentional or unintentional (Long 2003). In a survey of New Zealand scientific literature, Fitzgerald (1990) concluded that prey selection of feral and freeranging cats is dependent on availability. The author found that cats on mainland situations fed most heavily on mammals; whereas, cats on islands fed almost exclusively on birds (particularly seabirds). Feral and free-ranging cats are known to prey on birds as large as mallard ducks (Figley and VanDruff 1982) and young brown pelicans (Anderson et al. 1989) and mammals as large as hares and rabbits. Many of these cat populations rely heavily on humans, either for handouts or waste food stuffs, especially when prey populations are low.

Effects of predation on native species by feral cat populations are widespread and significant (Whittaker 1998). Cats have been one of the most important biological factors (excluding humans) causing the depletion or extinction of both island and mainland bird species (Nogales et al. 2004). In isolated environments such as islands, feral cats are directly responsible for a number of extinctions and extirpations worldwide and across multiple taxa (Towns et al. 1990; Veitch 2001; Long 2003). Jackson (1978) reports cats as the most significant factor, next to habitat destruction, contributing to the extinction of bird species. He reports that at least 33 species have become extinct as a result of cat predation; most of these are on islands.

Another significant problem created by cats is that they are reservoirs and transmitters of various diseases and parasites to both domestic and wild animal species, as well as to humans. Cats serve as reservoirs or hosts for dermatomycoses, fleas, scabies, gram-positive bacterial infections, cat scratch fever, distemper, histoplasmosis, leptospirosis, mumps, plague, 
rabies, ringworm, salmonellosis, toxoplasmosis, tularemia, and various endo- and ecto-parasities (Warner 1984; Fitzwater 1994).

If feral cats are so destructive to wildlife, especially on islands, why is there not a greater effort to control feral cat populations? The control of feral cats is a very controversial area as many members of the public and some advocacy groups are strong supporters of cats and are against the killing of feral cats. These persons and groups often prefer the trap-neuterrelease approach to feral cat management (Castillo and Clarke 2003). Some groups actually maintain feeding stations for feral cat colonies. These more socially acceptable methods of cat control have had limited success at reducing predation by feral cats, so most wildlife professionals and governmental agencies advocate the strict control or elimination of feral cat populations (Pech 2000; Parkes and Murphy 2002). The most commonly used methods to control or eliminate feral cats were trapping and shooting, although some countries also use toxic baits (Eason et al. 1992; Veitch 2001; Short et al. 2002; Wood et al. 2002; Hess et al. 2004). Nogales et al. (2004) identified 48 successful eradication efforts on islands. Most of these eradication efforts were on small unpopulated islands where the cat population is closed and the number of nontarget animals was low. In addition, seabirds can form extremely dense nesting colonies and the removal of predators can have dramatic effects.

\section{Mongoose}

Small Indian mongooses (Herpestes javanicus, synonymous with $\underline{\mathrm{H}}$. auropunctatus) were native to India, Pakistan, southern China, Java, Iran, and Iraq (Corbet and Hill 1992). Mongooses were introduced to combat rats in sugarcane fields during the late 1800s to early 1900s and snakes in Asia (Gorman 1975; Sugimura et al. 2005). As sugarcane production spread from the Caribbean and South America (Jamaica, Puerto Rico, and Cuba, etc.), to the Pacific (Hawaiian and Fiji islands), and then to other parts of the world, mongoose introductions followed (Nellis and Everard 1983; Long 2003). While they may kill some rodents, mongooses are mainly diurnal whereas rats are mainly nocturnal. Hence, mongooses are basically useless as a means of rodent damage control. Mongooses use many habitats from forests to open grasslands and the edges of villages and feed on a wide variety of vertebrate, invertebrate, and plant foods (Nowak 1991). Mongoose proved to be ineffective at controlling rats but were serious predators of native ground nesting birds, as well as other vertebrate species (Gorman 1975; Tomich 1986). Mongooses have been implicated in the demise of ground nesting birds and ground nesting bird reproduction has ceased in cases where mongooses are present (Baker and 
Russell 1979; Stone et al. 1994; Long 2003). In addition to the extinction or local extirpation of ground nesting birds worldwide, they have been implicated in the demise of frogs in Fiji, ground lizards and snakes on St. Croix, turtles on St. John, and small mammals in Japan and Puerto Rico (Seaman and Randall 1962; Gorman 1975; Nellis and Small 1983; Coblentz and Coblentz 1985; Vilella 1998; Sugimura et al. 2004). The successful reintroduction of endangered species where mongooses were the primary predator has been dependent on eradication of mongooses on select islands or in small areas (USFWS 1999). Beyond native wildlife, mongooses may have a great effect on poultry production and are a reservoir of rabies, leptospirosis and other diseases (Everard and Everard 1988; Pimental et al. 2000; Long 2003). Pimental et al. (2000) estimated that the mongoose causes about $\$ 50$ million in damages each year in Hawaii and Puerto Rico alone.

Trapping and toxicant baits have been used in attempts to eradicate mongoose or reduce high populations of mongooses near and around native bird nesting habitats (Smith et al. 2000; Roy et al. 2002). Although mongooses are easily trapped and are susceptible to several rodenticides, mongoose eradication has proven extremely difficult with few successes (Roy et al. 2002; Long 2003; Sugimura et al. 2004). If mongooses can be eradicated locally, fences may be an option to prevent reinvasion (Clapperton and Day 2001). Mongooses are long lived and have high reproductive capacity with a gestation period of 42 days and 1-4 offspring in each litter (Nowak 1991). Further, where mongooses have been introduced, they have few predators or competitors to restrict populations.

\section{Stoat or short-tailed weasel}

The stoat (Mustela ermine) was native to northern parts of Eurasia and North America and was recently introduced into New Zealand and has spread to several offshore islands to control rabbits (King 1989). Although invasive predators have already reduced many of New Zealand native species, the stoat has had significant effects on kiwi and forest birds (O’Donnell et al. 1996; Basse et al. 1999; McDonald and Murphy 2000). The species differs from mongoose in that stoats are more arboreal than the former and thus they may affect cavity nesting birds, as well as other vertebrates (Basse et al. 1999). Techniques for stoat control remain similar to mongoose control (Alterio et al. 1999; McDonald and Larivière 2001) 


\section{Red fox}

The red fox (Vulpes vulpes) is native to a large part of the northern hemisphere, but has been introduced to other parts of the world, notably Australia and many islands such as the Aleutian Islands of the United States (Long 2003). Their rapid range expansion throughout Australia was probably facilitated by the large prey base provided by previously introduced European rabbits. Foxes have been introduced for the fur industry and for sport hunting. They were introduced to islands off of Massachusetts (east coast of the United States) to control herring gull colonies and was so successful that foxes died from lack of food (Kadlec 1971). Foxes are adaptable and can use a wide range of habitats. Foxes are efficient predators, but will also consume fruit and vegetables. They prey on a wide array of small mammals and birds, but also eggs, young livestock and poultry, invertebrates, and carrion (Doncaster et al. 1990). They also feed on crustaceans and fish (Witmer and Lewis 2001). They have had substantial impacts on grounding nests bird populations, both in seabird colonies on islands and game bird populations on mainland situations (Witmer and Lewis 2001; Long 2003). In Australia, they have been implicated in the decline of several species of native marsupials (Kinnear et al.2002). Foxes also play a significant role in rabies epizootics (Anderson et al.1981).

Red foxes are managed with a variety of methods, including trapping, shooting, and poisonous baits. All of these methods were employed to eradicate red foxes from most of the Aleutian Islands (Ebbert 2000). Interestingly, a biological control method was successfully used on two small islands that had introduced arctic fox populations. Sterilized red foxes were put on those islands and the larger red foxes eliminated the arctic foxes and then eventually died out (Ebbert 2000).

\section{Feral pig}

Pigs (Sus scrofa) originated in Eurasia, were domesticated as livestock, and then moved around the world as an important food source (Long 2003). The lengthy list of introductions to continents and islands provided by Long (2003) clearly suggest that pigs are one of the most widely introduced mammalian species in the world. They were introduced to Florida in 1539, but had been brought much earlier to the islands of Hawaii and the West Indies (Long 2003). They have more recently been introduced to areas for sport hunting (Witmer et al. 2003). Captive pigs may escape captivity and successfully establish or supplement wild populations (Witmer et al. 2003). In the United States, feral swine occur in 
over 23 states and their numbers are estimated to exceed 4 million (Seward et al. 2004). They are the most abundant introduced ungulate in North America and their populations continue to expand (Sweeney et al. 2003). In addition to predation problems, feral pigs also cause substantial environmental damage (Seward et al. 2004; Sweeney et al. 2003) and pose significant disease hazards to livestock, humans, and wildlife (Witmer et al. 2003).

Feral pigs are omnivorous and will feed on a very wide variety of foods, both plant and animal (Henry and Conley 1972; Challies 1975; Seward et al. 2004). Plant materials include grasses, forbs, leaves, roots, seeds, shoots, fruits, and fungi. They also feed on a wide variety of cultivated crops and can cause substantial crop losses. Animal materials include fish, lizards, frogs, salamander, snakes, turtles, bird eggs and chicks, small rodents and rabbits, fawns, and small livestock. They also feed on a wide variety of invertebrates, including crabs, earthworms, leeches, snails, slugs, grasshoppers, centipedes, beetles, and many other insects. This broad range of foraging results in competition for food with wildlife (e.g., wild turkeys) and livestock, especially through the voracious consumption of mast (e.g., acorns). Nest destruction of the nests and eggs of ground nesting birds and sea turtles by feral pigs is significant in some areas (Seward et al. 2004). Feral pigs cause substantial losses to lamb production in Australia and in parts of the United States (California, Texas; Seward et al. 2004). Feral pigs are responsible for reducing many plant and animal populations resulting in these species being listed as endangered (Seward et al. 2004). On islands to which they have been introduced, they threaten ground-nesting seabirds, penguins, iguanas, and tortoises (Challies 1975; Wiewandt 1977; Long 2003; Seward et al. 2004). In Florida, they have destroyed up to $80 \%$ of sea turtle nests (Seward et al. 2004)

There were a variety of methods used to manage or eliminate feral pig populations, although eradication is difficult (Seward et al. 2004; Sweeney et al. 2003). Methods include trapping, shooting, pursuit with dogs, aerial shooting, night shooting over bait piles, exclusion fencing, and the use of toxicants. The use of toxicants is very limited in the United States because of non-target hazards, but they have been used extensively in Australia where there are many invasive mammals and nontarget hazards are minimal. Research is needed in management techniques such as population monitoring and oral delivery systems for disease vaccines, fertility control agents, and toxicants (Sweeney et al. 2003). 


\subsubsection{Birds}

\section{Cattle egret}

The cattle egret (Bulbulcus $\underline{\text { ibis) }}$ ) was originally native to Africa, southern Europe and eastward through southeastern Asia and northern Australia. Prior to 1900, the species began an enormous range expansion and arrived in South America in 1877 and in the United States in about 1941 (Telfair 1994). The species currently occurs throughout the continental United States, South America, and somewhat into Canada. Cattle egrets were introduced into Hawaii in 1959 to help control flies around homes and cattle pastures; they were introduced to the Seychelles, Frigate, and Praslin islands for the same reason (Long 1981). The species range continues to expand, potentially throughout the Pacific basin. The birds are well adapted to forage in grasslands occupied by large grazers. Human conversion of large areas to livestock pasture has probably facilitated the range expansion of cattle egrets. Cattle egrets also use urban-suburban parks and aquatic habitats, although they are not dependent upon the latter.

Cattle egrets are voracious active foragers (Telfair 1994). They usually feed in loose aggregations of 10 to 100 birds. They are opportunistic feeders, feeding mainly on invertebrates including grasshoppers, crickets, spiders, beetles, ticks, flies, moths, katydids, roaches, earthworms, millipedes, centipedes, crayfish and may feed on prawns at aquaculture facilities (Grubb 1976; Hancock and Elliott 1978; Telfair 1994). They will also eat small vertebrates, including frogs, toads, lizards, snakes, mice, the eggs and chicks of nesting birds, and even exhausted small migrant birds along shorelines. In Hawaii, they prey upon native waterbird and seabird chicks, including the native black-necked stilt (Stone and Anderson 1988). When feeding their chicks, an adult egret can consume over $50 \%$ of its body weight each day. These birds often forage near grazing livestock, wild ungulates or by farm machinery. They often forage in newly plowed or burned fields. They are often seen using the backs of large ungulates for perches. These "hosts" make foraging by egrets much more efficient. However, the cattle egret foraging strategy varies depending on the size of prey they are focusing on and they are not reliant on the these "hosts" to effectively forage (Grubb 1976). They have been known to scavenge food in tern colonies and even force tern chicks to regurgitate for them. Because of their voracious and diversified feeding habits, and because they forage in sizable groups, cattle egrets could have impacts on the populations of various native or endemic species but these effects have been poorly documented. Additional problems caused by egrets include bird strike hazards at airports because they forage in large groups in grasslands 
common to airports (Fellow and Paton 1988). Due to the continued range expansion and movement of egrets, they may be ideal carriers of disease organisms and large rookeries may be sanitation hazard near developed areas.

A variety of methods can be used to move cattle egrets from areas they are not wanted. These include shooting, harassment/scare devices, trapping, netting and shooting (Fellow and Paton 1988; Telfair 1994). Because cattle egrets are a migratory non-game bird, they receive protection under state and federal laws at most locations and so control options are limited.

Future research needs include a better understanding of interspecies interactions and why certain areas are selected for foraging, and continued study of parasites and potential disease transmission (Telfair 1994). A quantification of their impacts on rare, endemic faunal species is needed (Stone and Anderson 1988).

\section{Barn owl}

The barn owl (Tyto alba) is the most widespread of all owl species being found on all continents except Antarctica (Marti 1992). It has been introduced to various islands (Hawaii, Seychelles, St. Helena) and has colonized other islands on its own (Long 1981). They were introduced to Hawaii in 1958-1963 with the hope that they would control rats in sugarcane plantations (Long 1981). Barn owls use a wide array of habitats, especially grasslands and agricultural areas with nesting cavities nearby. They will readily nest in many human structures.

Barn owls primarily feed on small mammals, bats, and some birds (Speakman 1991; Marti 1992). Lizards and invertebrates are found only in trace amounts in the diet. It is probably safe to assume that the diet is variable, depending on prey species availability. For example, significant predation on bats was noted in Bolivia and the British Isles (Speakman 1991; Vargas et al. 2002). They consume about $10 \%$ of their body weight per day. Barn owls are known to prey on seabirds and probably compete with Hawaii's native short-eared owl and Hawaiian owl (Stone and Anderson 1988). In the Seychelles, they preyed on numerous native birds, especially fairy and bridled terns (Long 1981; Bowler et al.2002). A successful barn owl control program has greatly reduced barn owl predation since 1996 (Bowler et al.2002).

A variety of methods can be used to move barn owls from areas they are not wanted. These include shooting, harassment/scare devices, trapping, netting and shooting. Because barn owls are a non-game species and a migratory bird species, they receive protection under state and federal laws 
at most locations. Future research needs include a better understanding of interspecies interactions and a quantification of barn owl impacts on rare, endemic faunal species is needed (Stone and Anderson 1988).

\subsubsection{Reptiles}

\section{Brown treesnakes}

Brown treesnakes (Boiga irregularis) were accidentally introduced into Guam shortly after World War II from their native range in Australia and Papua New Guinea and Australia. The snakes are slender and arboreal with a typically adult length of about $2 \mathrm{~m}$. They have reached extremely high population levels ( $>40$ per hectare) on Guam because of the abundance of food and lack of abundant predators. The large snake population levels have resulted in the extirpation of most of Guam's native forest birds ( 9 of 11), extirpation of native lizard populations ( 9 of 12), and extirpation of two of the three native bats (Savidge 1987; Savidge 1988; Rodda and Fritts 1992; Rodda et al. 1997). Beyond the severe ecological effects, brown treesnakes have been a threat to human health and safety, agriculture, and cause frequent power outages. The snakes are poisonous rear-fanged snakes, thus they are unlikely to cause harm to adults. However, they may affect small children. Data from a single hospital in Guam suggests that there may be more than 26 bites per year (OTA 1983). Pets and poultry also are frequent prey items of the snakes. The largest economic impact from the snakes is the disruption of power systems. The arboreal snake frequently climbs utility poles, power lines, and other structures as travel corridors. Thus, snakes ground out these systems when they cross from grounded to live structures causing an estimated 1.4 million in damages from power outages (Vice and Pitzler 2002).

A variety of methods are employed to control snakes and restrict their access to aircraft and cargo leaving the islands including fence searches, trapping with mice, and searching with detector dogs (Vice et al. 2005). Other potential methods to control snakes include the use of toxicants, repellents, reproductive inhibition, and barriers but these have yet to be deployed over large areas for eradication.

\section{Burmese pythons}

Burmese pythons (Python molurus bivittatus) became established in Everglades National Park during the 1990s as the result of unwanted or accidentally released pets (S. Snow, National Park Service, pers. comm.). 
Burmese pythons are large snakes $(>7 \mathrm{~m})$ with high reproductive rates. Originally from Southeast Asia, pythons are common pets in the United States (Pough et al. 1998). Pythons may compete with native snake species, prey on many native mammals and birds, and transmit disease to native reptiles. The number of snakes removed has increased during the past few years and this could represent a rapidly increasing population (S. Snow, unpubl. data.). Biological information on pythons is limited but potential habitat includes much of the Southeastern United States. Sources of mortality for the snakes in the Everglades National Park include motor vehicles, mowing equipment, fire, and possibly alligators (S. Snow, unpubl. data). Currently, management actions center on mechanical control and education efforts to prevent further introductions. Mechanical control techniques include trapping, hand capture, and early detection using dogs.

\section{Nile monitor lizard}

The Nile monitor lizard (Varanus niloticus) is native to Africa where it is the longest $(2.1 \mathrm{~m})$ lizard (Enge et al. 2004). They are imported for the pet industry, but their size and aggressive temperament probably limits their value as pets. They were first observed in the wild in southern Florida in 1990; since that time there have been 146 sightings or captures with all size classes present, suggesting a reproducing population (Enge et al. 2004). The lizard has a high reproductive capability, laying up to 60 eggs in a clutch (de Buffrenil and Rimblot-Baly 1999).

Nile monitor lizards are voracious predators. In their native range, they feed on wide array of freshwater, marine, and terrestrial prey, including shellfish and other invertebrates, fish, amphibians, reptiles, mammals, birds, and bird eggs (Enge et al. 2004). Cooperative hunting and nest robbing have been observed in the species. They readily inhabit human settlements and even forage around garbage dumps (Enge et al. 2004). In Africa, they compete with dwarf crocodiles, with crabs being the main prey of both species (Luiselli et al. 1999). This suggests that they could compete with the American alligator and the American crocodile (an endangered species) in Florida. Furthermore, the extensive canal systems of southern Florida provide ideal dispersal corridors for the lizards. Other native species that could be threatened by the monitor lizards should their population and range increase in Florida include sea turtles and diamondback terrapins because of egg predation, brown pelicans (a threatened species), burrowing owls, and gopher tortoises (Enge et al. 2004).

An eradication strategy for the Nile monitor lizard in Florida has been proposed (Campbell 2005). There would require an extensive and 
intensive trapping effort over a minimum of two years (Campbell 2005). At present, detection, monitoring, and trapping strategies are rudimentary, limiting efforts to control this species.

\subsubsection{Amphibians}

\section{Bullfrogs}

Bullfrogs (Rana catesbeiana) from the eastern United States were widely introduced from 1900-1940 into many western states including Hawaii as food resource. Bullfrogs have had significant ecological effects and have been difficult to control because they are highly mobile, have generalized eating habits, and have high reproductive capacity (Moyle 1973). Bullfrogs may cause the extirpation of other species due to intense predation and competition (Kats and Ferrer 2003). Management of bullfrog populations is difficult, due to commingling with native species in aquatic habitats. Adult frogs are removed by trapping or hand captures and tadpoles are destroyed by draining ponds or chemical treatment where feasible. Fencing may also be used to limit frog movements away from infested habitats.

\section{Cane toads}

Giant neotropical (Bufo marinus) or cane toads were widely introduced from Central America into sugar cane producing regions worldwide to control beetles causing damage to crops (McKeown 1978). However, the effort had very limited success because the beetles could climb into the vegetation away from the toads. Cane toads may compete with native species for food, compete with native amphibians for breeding sites, and prey on a variety of invertebrate and vertebrate species (McCoid 1995; Williamson 1999). Cane toads can be very active nest predators of birds and have a significant effect on native fauna (Boland 2004) Further, native species preying on cane toads may be poisoned by the toad's parotoid gland secretions (McCoid 1995).

The frogs also may be a nuisance when large numbers congregate for breeding in ponds or water features. Australia has been aggressively pursuing control options but has had little success in developing new methods (Luntz 1998). Currently, the only effective strategies are pond drying, hand capture, and trapping. 


\section{Coqui frogs}

The coqui frog (Eleutherodactylus coqui) was introduced into Hawaii during the late 1980s likely from infested plant shipments from Puerto Rico (Kraus et al. 1999). Sizeable populations are now found on the islands of Hawaii, Maui, Oahu, and Kauai and the frog threatens Hawaii's multi-million dollar floriculture, nursery, real estate, and tourist industries, as well as its unique ecological systems (Beard and Pitt 2005). Most of the coqui affects stem primarily from a piercing call (80-90 dBA at $0.5 \mathrm{~m})$ and from extremely high population densities that have exceeded 50,000 individuals ha ${ }^{-1}$ in Hawaii (Beard and Pitt 2005). Beyond being a noise nuisance, the loud nighttime choruses of frogs has affected real estate values because people desire a coqui free property (Kaiser et al. 2006). The floriculture industry may also be affected by refused shipments, reduced sales, and costs associated with control and quarantine efforts. Moreover, the high densities of frogs may effect native insect populations, forest nutrients, compete with native birds and bats, and alter ecosystem processes (Beard and Pitt 2005). The frogs may also benefit other invasive predators, but there is little evidence that rats, mongoose, or cane toads benefit from frogs as prey (Beard and Pitt 2006). Brown treesnakes typically require small prey as juveniles and the presence of another abundant food source in the Hawaii could increase the chance of brown treesnakes establishing a population if they arrive on the islands. However, there is already abundant food resources in the Hawaiian Islands, including geckos, birds, and small mammals (Shine 1991).

Due to the high densities of frogs and their present range, few options exist for control of wild populations. Mechanical controls include hand capturing, habitat alteration, and trapping. These mechanical methods only work on a small scale with a few populations. However, some success has been documented using hot water treatments for plant shipments. A hot $\left(>45{ }^{\circ} \mathrm{C}\right)$ water treatment for at least 3 minutes will kill adult frogs and eggs (UH 2006). Biological control or the release of organisms to combat the frog likely will have little success and could have many unintended consequences. Unfortunately, disease organism have a low potential for controlling coqui frogs in Hawaii, primarily because viruses and diseases are most effective when applied to small populations of species with low reproductive capacity (Brauer and Castillo-Chavez 2001, Daszak et al. 2003). In large populations, diseases may initially induce temporary population declines, but subsequently surviving resistant individuals may lead to population levels similar to those prior to treatment. In addition, frogs could carry a virus or disease to other parts of the world where frog conservation is the priority (Angulo and Cooke 2002). Another important 
consideration is that most of the major frog diseases infect tadpole stages (Daszak et al. 2003). Because coqui frogs do not have a tadpole stage, they are less likely to be effected. Although many frogs are quite susceptible to a variety of chemicals, the terrestrial coqui frog has been unaffected by a wide range of potential pesticides. Currently, only citric acid and hydrated lime have proven to be effective and registered to use to combat the frogs (Pitt and Sin 2004a). Although these chemicals are effective if sprayed directly on the frogs, there are several limitations with these products including varying effectiveness due to weather conditions, potential phytotoxicity to plants, the cost of repeated spraying large areas, access to remote or private land, and other factors (Pitt and Sin 2004b).

\subsubsection{Fish}

Humans have moved fish around the world at least back to the time of the Romans (Moyle 1986). Moyle (1986) reviewed fish introductions in North America and noted that at least 150 species have been involved. Fish are introduced for various reasons, including as a source of food, for recreational fishing, as ornamentals, and to help with aquatic insect and plant control. Unfortunately, some of the species are voracious predators and can inflict great harm on native aquatic fauna. The salmonids and perches are perhaps the most significant predators in this group. Recently, some states and countries have only been stocking sterile fish to prevent breeding with native stocks and to restrict population growth. The list of the world's 100 worst invasive alien species includes brown trout (Salmo $\underline{\text { trutta) }}$ and rainbow trout (Oncorhynchus mykiss) from the first group and large-mouth bass (Micropterus salmoides) and Nile perch (Lates niloticus) from the second group (Lowe et al. 2004). A more recent threat is transporting and releasing fish through the pet trade (McNeely and Schutyser 2003). Aquarium fish represent a huge reservoir of potential invasive species with more than 5000 fish species traded globally and little is known of their potential effects (McDowall 2004). In the United States, up to $65 \%$ of the established nonnative fish populations species likely originated from the aquarium fish trade (Courtenay and Stauffer 1990). In Australia, $77 \%$ of nonnative fish originated from the aquarium fish trade (Koehn and MacKenzie 2004). The walking catfish (Clarias batrachus) is a voracious predator that has been transported to the United States and other countries via the pet trade and for aquaculture. Once introduced, they may spread throughout adjacent waterways and may significantly reduce native 
fish populations; many other species currently in the pet trade have similar potential (Simberloff et al. 1997).

Predacious fish have broad food habits and will consume invertebrates, amphibians, reptiles, and small fish. Drastic changes in a fish fauna can occur when the native fishes are not adapted to the style of predation of the introduced fish and extinctions and severe declines in the native species usually results (Moyle 1986; Moyle and Cech 1996). The Nile perch after arriving in Lake Victoria in the early 1960s and within 30 years more than 200 hundred fish species had disappeared and the perch became the main fishery species in the lake in the 1990s (Witte et al. 1990; Kitchell et al. 1997). Presumably, competition from introduced fish also causes declines in native fishes, but is more difficult to demonstrate (Moyle and Cech 1996). In Japan, large-mouth bass introduced to ponds reduced fish, shrimp, crayfish, and insects number (Maezono et al. 2005). Negative impacts of introduced predacious fish on native amphibian populations have been documented in Russia (Reshetnikov 2003), Australia (Gillespie 2001), Europe (Martinez-Solano et al. 2003), and North America (Bull and Marx 2002). With removal of the introduced fish, some amphibian populations recover relatively quickly (Hoffman et al. 2004).

Introduced fish species are often difficult to control or eliminate once established. Gill nets are used in some situations (Hoffman et al. 2004). In extreme pond or lake situations, a chemical toxicant such as rotenone is used to kill all fish; then restocking with native species can occur. More effective and species-specific methods are needed for managing or eliminating introduced predacious fish.

\subsection{Regulation of invasive species}

The regulation of wildlife, in general, and introduced species in particular varies by country and even within regions, territories, provinces or states of a specific country (Witmer and Lewis 2001). In general, the regulatory authority to manage wildlife is held at a fairly local level (e.g., state or province or territory). The central governments of many countries often retain regulatory authority in some situations, such as migratory species, endangered species, and species that might cause significant economic harm. In the United States, many federal laws exist that have some involvement with invasive species, but the federal government very limited legal authority to manage the transportation of vertebrate invasive species across state boundaries or the resources to implement regulations 
restricting invasive species movement (National Invasive Species Council 2001).

Unfortunately, most species of exotic animals are considered "innocent until proven guilty" in many countries. There has been debate over the use of "white lists" and "black lists" in the regulation of animal imports. After conducting risk assessments, one can list which species are allowed entry into the country (white lists), or one can list only those species that are categorically excluded from entry (black list, Ruesink et al.1995, National Invasive Species Council 2001). Currently, in the United States, the latter approach is used, and only a few vertebrates are categorically excluded as "injurious wildlife." These include hedgehogs, brush-tailed possums, and brown tree snakes. Many federal and state agencies and international and national non-governmental organizations have put forth guidelines and policy statements on invasive wildlife (including the need for white-blackgray lists), but these have only been implemented in a few countries (see discussion in Witmer and Lewis 2001). Currently, there are procedures in place for the listing species that are known to be invasive; such listings may be petitioned and involve stakeholders and the public in the course of the rule-making process (National Invasive Species Council 2001). Other countries, such as New Zealand, have white lists, which are ultimately more effective at stemming the tide of invasive species. However, there are problems with this approach as well. Many of the species listed on white lists are actually genera in New Zealand, thus one genera listed could contain more than 800 species with many species having unknown effects (McDowall 2004). Further, government agents must be able to accurately identify the species, hybrid, or subspecies in all stages development to effectively restrict or allow importation. Unfortunately, until better regulations are in place and adequate funds are made available for inspections and management, we can expect many more invasive species situations to arise.

\subsection{Priorities of invasive species}

The priorities of invasive species management may be cleanly divided by the point that a species is established. Prior to establishment of a population, research and funding should go to prevention and early detection to decrease the potential for species becoming a problem (Park 2004). To increase the effectiveness of limited funding, a risk analysis should be performed to determine the threat from nonnative species and promote awareness of species that could cause significant effects. Further, 
coordination and cooperation among state and local agencies decreases the potential for duplicated efforts and increases the response efforts for incipient species. After a species has become established, research and funding is shifted to documenting effects of the species on ecological services, agriculture, and local economies. Development of control strategies and public awareness are priorities after establishment to control the effects of the new species.

Unfortunately, the line that separates the priorities before and after establishment may be referred to as the money line. Prior to a species becoming firmly established, the cost to control a species is low and the probability of success is high (Simberloff 2003; Park 2004). However, the amount of funding available and the public interest in dealing with the potential problem is extremely low at this time. Funding for research and interdiction efforts prior to species establishment is low and only secured with public support pressuring public officials. After the species is established, funding typically becomes more available and public interest in dealing with the issue is higher. Conversely, the costs of control sky rocket and the probability of success drops precipitously. This same scenario has been repeated in many areas with many new species. A recent example is the above mentioned case of the coqui frog in Hawaii. Although the species became established by the late 1980s in a few locations, no funding was available even though the potential to eradicate was still fairly high. The primary public opinion was that this was not a major problem and there were likely to be few negative consequences of this introduction and control efforts could be harmful. This attitude existed even after repeated warnings by scientists (see Kraus and Campbell 2002 for a full discussion). Fifteen years later, the public opinion is extremely supportive of dealing with the issue and several studies have documented the effects of the frogs on ecological communities, real estate, agriculture, and human health (Beard and Pitt 2005; Kaiser et al. 2006). However, the likelihood of complete eradication now is low and would require extensive resources.

In conclusion, invasive predators are an increasing problem throughout the world and these effects are becoming magnified as available habitat is lost. These predators cause a diverse array of problems, cannot be easily predicted, and may cause more significant problems on island ecosystems than mainland areas. The number of new introductions is likely to escalate if the many pathways of invasion are not controlled. Currently, there are few options to control established invasive species and the cost for control efforts is high once a species becomes widespread and causes significant effects. The most cost effective approach to invasive species management 
is to secure funding for research and interdiction efforts prior to a species becoming widespread.

\section{References}

Alterio N, Moller H, Brown K (1999) Trappability and densities of stoats (Mustela erminea) and ship rats (Rattus rattus) in a South Island Nothofagus forest, New Zealand. New Zealand. Journal of Ecology 23: 95-100

Anderson DW, Kieth JO, Trapp GR, Gress F, Moreno LA (1989). Introduced small ground predators in California brown pelican colonies. Colonial Waterbirds 12: 98-103

Anderson RM, Jackson HC, May RM, Smith AM (1981) Population dynamics of fox rabies in Europe. Nature 289: 765-771.

Angulo E, Cooke B (2002) First synthesize new viruses then regulate their release? The case of the wild rabbit. Molecular Ecology 11: 2703-2709

Atkinson IAE (1977) A reassessment of factors, particularly Rattus rattus L., that influenced the decline of endemic forest birds in the Hawaiian Islands. Pacific Science 31: 109-133

Atkinson IAE (2001) Introduced mammals and models for restoration. Biological Conservation 99: 81-96

Baker RH, Russel CA (1979) Mongoose predation on nesting nene. 'Elapaio 40: $51-52$

Basse B, McLennan JA, Wake GC (1999) Analysis of the impact of stoats, Mustela erminea, on northern brown kiwi, Apteryx mantelli, in New Zealand. Wildlife Research 26: 227-237

Beard KH, Pitt WC (2005) Ecological consequences of the coqui frog invasion in Hawaii. Diversity and Distributions 11: 427-433

Beard KH, Pitt WC (2006) Potential predators of an invasive frog (Eleutherodactylus coqui) in Hawaiian forests. Journal of Tropical Ecology 22: $1-3$

Blackburn TM, Cassey P, Duncan RP, Evans KL,Gaston KJ (2004) Avian extinction and mammalian introductions on oceanic islands. Science 305: 1955-1958

Boland, CRJ (2004) Introduced cane toads Bufo marinus are active nest predators and competitors of rainbow bee-eaters Merops ornatus: observational and experimental evidence. Biological Conservation 120: 53-62

Bowler J, Betts M, Bullock I, Ramos JA (2002) Trends in Seabird Numbers on Aride Island Nature Reserve, Seychelles 1988-2000. Waterbirds 25: 26-38.

Brauer F, Castillo-Chavez C (2001) Mathematical models in population biology and epidemiology. Texts in applied Mathematics. Springer Verlag, New York, United States

Bull EL, Marx DB (2002) Influence of fish and habitat on amphibian communities in high elevation lakes in northeastern Oregon. Northwest Science $76: 240-248$ 
Campbell TS (2005) Eradication of introduced carnivorous lizards from the Cape Coral area. Final report to the Charlotte harbor National Estuary Program, Fort Myers, Florida 1-30

Case TJ, Bolger DT (1991) The role of introduced species in shaping the distribution and abundance of island reptiles, Evolutionary Ecology 5: $272-$ 290

Cassey P, Blackburn TM, Jones KE, Lockwood JL. (2004) Mistakes in the analysis of exotic species establishment: source pool designation and correlates of introduction success among parrots (Aves: Psittaciformes) of the world. Journal of Biogeography 31: 277-284

Castillo D, Clarke A (2003) Trap-neuter-release methods ineffective in controlling domestic cat "colonies" on public lands. Natural Areas Journal 23, 247-253

Challies CN (1975) Feral pigs (Sus scrofa) on Auckland Island: status, and effects on vegetation and nesting sea birds. New Zealand Journal of Zoology 2: 47990

Chen T, Lue K (1998) Ecological notes on feral populations of Trachemys scripta elegans in northern Taiwan. Chelonian Conservation and Biology 3: 87-90

Churcher P, Lawton J (1987) Predation by domestic cats in an English village. Journal of Zoology (London) 212: 493-455

Clapperton KD, Day TD (2001) Cost-effectiveness of exclusion fencing for stoat and other pest control compared with conventional control. DOC Science Internal Series 14. Department of Conservation, Wellington, New Zealand

Clout MN, Ericksen K (2000) Anatomy of a disastrous success: the brushtail possum as an invasive species. In Montague $\mathrm{T}$ (ed) The Brushtail Possum: Biology, Impact and Management of an Introduced Marsupial. Landcare Research, Lincoln, New Zealand. 1-9

Coblentz, BE, Coblentz BA (1985) Control of the Indian mongoose Herpestes auropunctatus on St. John, US Virgin Islands. Biological Conservation 33: 281-288

Corbet GB, Hill JE (1992) The mammals of the Indomalayan region: a systematic review. Oxford University Press.

Courtenay WR Jr., Stauffer JR Jr. (1990) The introduced fish problem and the aquarium fish industry. Journal of the World Aquaculture Society 21: 145159

Cowan PE (2001) Advances in New Zealand mammalogy 1999-2000: brustail possum. Journal of the Royal Society of New Zealand 31: 15-29

Darwin C (1872) The origin of species, $6^{\text {th }}$ Edition. John Murray, London, United Kingdom.

Daszak P, Cunningham AA, Hyatt AD (2003) Infectious disease and amphibian population declines. Diversity and Distributions 9: 141-150

De Buffrenil V, Rimblot-Baly F (1999) Female reproductive output in exploited Nile monitor lizard populations in Sahelian Africa. Canadian Journal of Zoology 77: 1530-1539

Doncaster CP, Dickman CR, Macdonald DW (1990) Feeding ecology of red foxes (Vulpes vulpes) in the city of Oxford, England. Journal of Mammalogy, 71: 188-194 
Eason C, Morgan D, Clapperton B (1992) Toxic bait and baiting strategies for feral cats. Proceedings of the Vertebrate Pest Conference 15: 371-376

Ebbert S (2000) Successful eradication of introduced arctic foxes from large Aleutian Islands. Proceedings of the Vertebrate Pest Conference 19: 127-132

Elton CS (1958) The ecology of invasions by animals and plants. Methuen and Co., Ltd., London, United Kingdom

Enge KM, Krysko KL, Hankins KR, Campbell TS, King FW (2004) Status of Nile monitor in southwestern Florida. Southeastern Naturalist 3: 571-582.

Everard CO, Everard JD (1988) Mongoose rabies. Review of Infectious Diseases 10 (4): S610-614

Fellow DP, Paton PWC (1988) Behavioral response of cattle egrets to population control measures in Hawaii. Proceedings of the Vertebrate Pest Conference 13: $315-318$

Figley WK, VanDruff LW (1982) The ecology of urban mallards. Wildlife Monograph No. 82, The Wildlife Society, Bethesda, Maryland, USA.

Fitzgerald BM (1990) House cat. In King C.M (ed) The handbook of New Zealand mammals. Oxford University Press, Auckland, New Zealand 330348

Fitzwater W (1994) House cats (feral). In Hygnstrom S, Timm R, Larson G (eds) Prevention and control of wildlife damage. University of Nebraska Cooperative Extension Service, Lincoln, Nebraska, United States. C-45 - C49

Gillespie GR (2001) The role of introduced trout in the decline of the spotted tree frog in south-eastern Australia. Biological Conservation 100: 187-198

Gorman, ML (1975) The diet of feral Herpestes auropunctatus (Carnivora: viveriidae in the Fijiian Islands. Journal of Zoology 175: 273-278.

Griffin CR, King CM, Savidge JA, Cruz F, Cruz JB (1989) Effects of introduced predators on island birds: contemporary case histories from the Pacific. In Ouelle V (ed), Proceedings of the XIX Ornithological Congress. 1: 687-698

Groombridge B, editor (1992) Global biodiversity. Status of the Earth's living resources. Chapman \& Hall, London, England.

Grubb TC (1976) Adaptiveness of foraging in the cattle egret. Wilson Bulletin 88: $145-148$

Hancock J, Elliot H (1978) The Herons of the World. Harper and Row Publishing, New York, United States

Henry VG, Conley RH (1972) Fall foods of European wild hogs in the Southern

Appalachians. Journal of Wildlife Management 36: 854-60

Hess SC, Banko PC, Goltz DM, Danner RM, Brinck KW (2004) Strategies for reducing feral cat threats to endangered Hawaiian birds. Proceedings of the Vertebrate Pest Conference 21: 21-26

Hoffman RL, Larson GL, Samora B (2004) Responses of Ambystoma gracile to removal of introduced nonnative fish from a mountain lake. Journal of Herpetology 38: 578-585

Jackson JA (1978) Alleviating problems of competition, predation, parasitism, and disease in endangered birds. In Temple $\mathrm{S}$ (ed) Endangered birds: 
management techniques for preserving threatened species. Proceedings of the Symposium on Management Techniques for Preserving Endangered Birds. University of Wisconsin Press, Madison, Wisconsin, United States. 75-84

Kadlec JA (1971) Effects of introducing foxes and raccoons on herring gulls colonies. J Wildl Manage 35: 625-636

Kaiser B, Pitt WC, Burnett K (2006) Economic impact of coqui frogs in Hawaii. Proceedings of Ecology in an era of globalization, Ecological Society of America. Merida, Mexico.

Kats LB, Ferrer RP (2003) Alien predators and amphibians declines: Review of two decades of science and the transition to conservation. Diversity \& Distributions 9: 99110

King C (1989) The natural history of weasels and stoats. Christopher Helm, London.

King WB (1985) Island birds: will the future repeat the past? In Moors PJ (ed). Conservation of island birds. International Council for Bird Preservation Technical Publication No. 3. Cambridge, United Kingdom 3-15

Kinnear JE, Sumner NR, Onus ML (2002) The red fox in Australia-an exotic predator turned biocontrol agent. Biological Conservation 108: 335-35

Kitchell JF, Schindler DE, Ogutu-Ohwayo R, Reinthal PN (1997) The Nile Perch in Lake Victoria: Interactions Between Predation and Fisheries. Ecological Applications 7: 653-664

Koehn JD, Mackenzie RF (2004) Priority management actions for alien freshwater fish species in Australia. New Zealand Journal of Marine and Freshwater Research 38: 457-472

Kraus F, Campbell EW (2002) Human-mediated escalation of a formerly eradicable

problem: the invasion of Caribbean frogs in the Hawaiian Islands. Biological Invasions 4: 327-332

Kraus F, Campbell EW, Allison A, Pratt T (1999) Eleutherodactylus frog introductions to Hawaii. Herpetological Review 30: 21-25

Lockwood JL (1999) Using Taxonomy to Predict Success among Introduced Avifauna: Relative Importance of Transport and Establishment. Conservation Biology 13: 560-567

Long JL (1981) Introduced birds of the world. University Books, New York, United States.

Long JL (2003) Introduced mammals of the world. CSIRO Publishing, Canberra, Australia.

Lowe S, Browne M, Boudjelas S, De Poorter M (2004) 100 of the world's worst invasive alien species. World Conservation Union (IUCN), Gland, Switzerland.

Luiselli L, Akani GC, Capizzi D (1999) Is there any interspecific competition between Dwarf Crocodiles (Osteolaemus tetraspis) and Nile Monitors (Varanus niloticus) in the swamps of central Africa? Journal of Zoology, London 247: 127-131

Luiselli L, Capula M, Capizzi D, Filippi E, Jesus VT, Anibaldi C (1997) Problems for conservation of pond turtles (Emys orbicularis) in central Italy: is the 
introduced red-eared turtle (Trachemys scripta) a serious threat. Chelonian Conservation and Biology 2: 417-419

Luntz S (1998) Virus can't be used to control cane toads. Australasian Science 19: $10 \mathrm{pp}$

Maezono Y, Kobayashi R, Kushahara M, Miyashita T (2005) Direct and indirect effects of exotic bass and bluegill on exotic and native organisms in farm ponds. Ecological Applications 15: 638-650

Marti CD (1992) Barn owl. In Poole A, Gill F (eds) The Birds of North America. The Academy of natural Science, Philadelphia 1-16

Martinez-Solano I, Barbadillo LJ, Lapena M (2003) Effect of introduced fish on amphibian species richness and densities at a montane assemblage in the Sieer de Neila, Spain. Herteptological Journal 13: 167-173

McCoid MJ (1995) Non-native reptiles and amphibians. In Laroe, ET, Farris GS, Puckett CE, Doran PD, Mac MJ (eds) Our living resources: a report to the nation on the distribution, abundance, and health of U.S. plants, animals, and ecosystems. U.S. Department of the Interior, National Biological Service, Washington, D.C., United States 433-437

McDonald RA, Larivière S (2001) Review of international literature relevant to stoat control. Science for Conservation 170. Department of Conservation, Wellington, New Zealand

McDonald RA, Murphy EC (2000) A comparison of the management of stoats and weasels in Great Britain and New Zealand. In Griffiths HI. (ed) Mustelids in a modern world. Backhuys Publishers, Leiden, The Netherlands 21-40

McDowall RM (2004) Shoot first, and then ask questions: a look at aquarium fish imports and invasiveness in New Zealand. New Zealand Journal of Marine and Freshwater Research 38: 503-510

McKeown S (1978) Hawaiian reptiles and amphibians. Oriental Publishing Company Honolulu. United States

McNeely JA, Schutyser F (2003) Invasive Species: a global concern bubbling to the surface. International Conference on the Impact of Global Environmental Problems on Continental and Coastal Marine Waters, Geneva, Switzerland

Mooney HA, Hobbs RJ, Editors. 2000. Invasive Species in a Changing World. Island Press, Washington, D.C. United States

Moyle PB (1973) Effects of introduced bullfrogs, (Rana catesbeiana), on the native frogs of the San Joaquin Valley, California. Copeia 1: 18-22

Moyle PB (1986) Fish introductions into North America: patterns and ecological impact. In Billings WD, Golley F (eds) Ecological Studies 58: Ecology of biological invasions of North America and Hawaii. Springer-Verlag, New York 27-43

Moyle PB, Cech JJ (1996) Fishes: an introduction to ichthyology. Prentice Hall, Upper Saddle River, New Jersey, United States

Murdoch WW (1969) Switching in general predators: experiments on predators specificity and stability of prey populations. Ecological Monographs 39: 335354

Myers JH, Simberloff D, Kuris AM, Carey JR (2000) Eradication revisited: dealing with exotic species, Trends in Ecology \& Evolution 15: 316-320 
National Invasive Species Council (2001) Meeting the national invasive species challenge: national invasive species management plan. United States Department of Interior, Washington, D.C. United States

Nellis DW, Everard COR (1983) The biology of the mongoose in the Caribbean Islands. Studies on the Fauna of Curacao and other Caribbean Islands 64: 1162

Nellis DW, Small V (1983) Mongoose predation on sea turtle eggs and nests Biotropica 15: 159-160

Nogales N, Martin A, Tershy BR, Donlan CJ, Veitch D, Puerta N, Wood B, Alonso J. (2004) A review of feral cat eradication on islands. Conservation Biology 18: 310-319

Nowak RM (1991) Walker's mammals of the world II, Fifth edition, Johns Hopkins University Press, Baltimore, Maryland, United States

O’Donnell CFJ, Dilks PJ, Elliott GP (1996) Control of a stoat (Mustela erminea) population irruption to enhance mohua (yellowhead) (Mohoua ochrocephala) breeding success in New Zealand. New Zealand Journal of Zoology 23: 279286

OTA (Office of Technology Assessment) (1993) Harmful Non-Indigenous Species in the United States. Washington (DC): Office of Technology Assessment, US Congress, United States

Park K (2004) Assessment and management of invasive alien predators. Ecology and Society $9,12-28$

Parkes J, Murphy E (2002) Management of introduced mammals in New Zealand. New Zealand Journal of Zoology 30: 335-359

Pech R (2000) Biological control of vertebrate pests. Proceedings of the Vertebrate Pest Conference 19, 206-211

Pell AS, Tidemann CR (1997). The impact of two exotic hollow-nesting birds on two native parrots in savannah and woodland in eastern Australia. Biological Conservation 79: 145-153

Pimental D, Lech L, Zuniga R, Morrison D (2000) Environmental and economic costs associated with non-indigenous species in the United States. BioScience 50: 53-65

Pitt WC, Sin H (2004a) Dermal toxicity of citric acid based pesticides to introduced Eleutherodactylus frogs in Hawaii. USDA, APHIS, WS, NWRC. Hilo, Hawaii, United States

Pitt WC, Sin H (2004b) Testing citric acid use on plants. Landscape Hawaii July/August 5/12

Pough FH, Andrews RM, Cadle JE, Crump ML, Savitzky AH, Wells KD (1998)

Herpetology, Prentice Hall Inc. United States

Reshetnikov AN (2003) The introduced fish, rotan, depresses populations of aquatic animals (macroinvertebrates, amphibians, and a fish). Hydrobiologia 510: 83-90

Rodda GH Fritts TH (1992) The impact of the introduction of the colubrid snake Boiga

irregularis on Guam's lizards. Journal of Herpetology 26: 166-174

Rodda GH, Fritts TH, Chiszar D (1997) The disappearance of Guam's 
wildlife. BioScience 47: 565-574

Roy S, Jones C, Harris S (2002) An ecological basis for control of the mongoose in Mauritius: is eradication possible? In Veitch C, Clout M (eds) Turning the tide: the eradication of invasive species. World Conservation Union (IUCN), Gland, Switzerland 266-273

Ruesink JL, Parker IM, Groom MJ, Kareiva PM (1995) Reducing the Risks of Nonindigenous Species Introductions BioScience 45: 465-477

Savidge JA (1987) Extinction of an island forest avifauna by an introduced snake. Ecology 68, 660-668

Savidge JA (1988) Food habits of Boiga irregularis, an introduced predator on Guam. Journal of Herpetology 22: 275-282

Seaman G, Randall J (1962) The mongoose as a predator in the Virgin Islands. Journal Mammalogy 43: 544-546

Seidel ME, Franz R (1994) Amphibians and reptiles (exclusive of marine turtles) of the Cayman Islands. In Brunt MA and Davies JE (eds) The Cayman Islands: natural history and biogeography. Kluwer Academic Publishers, The Netherlands 407-434

Seward NW, VerCauteren KC, Witmer GW and Engemann RM (2004) Feral swine impacts on agriculture and the environment. Sheep and Goat Research Journal 19: 34-40

Shine R (1991) Strangers in a strange land: ecology of Australian colubrid snakes. Copeia 1991: 120-131

Short J, Turner B, Risbey D (2002) Control of feral cats for nature conservation. Wildlife Research 29: 475-487

Simberloff D (1995) Why do introduced species appear to devastate island more than mainland areas? Pacific Science 49: 87-97

Simberloff, D (1996) Impacts of introduced species in the United States. Consequences 2: 13-24.

Simberloff D (2003) How much information on population biology is needed to manage introduced species. Conservation Biology 17, 83-92.

Simberloff D, Schmitz DC, Brown TC (1997) Strangers in Paradise: Impact and Management of Nonindigenous Species in Florida, Island Press, Washington D.C., United States

Simberloff D, Von Holle B (1999) Positive interactions of nonindigenous species: invasional meltdown? Biological Invasions 1:21-32

Smith DG, Polhemus JT, VanderWerf EA (2000). Efficacy of fish-flavored diphacinone bait blocks for controlling Small Indian Mongooses (Herpestes auropunctatus) populations in Hawaii. 'Elepaio 60: 47-51

Speakman JR (1991) The impact of predation by birds on bat populations in the British Isles. Mammal Review 21: 123-142

Stone CP, Anderson SJ (1988) Introduced animals and Hawaii's natural area. Proceedings of the Vertebrate Pest Conference 13: 134-140

Stone CP, Dusek M, Aeder, M (1994) Use of an anticoagulant to control mongooses in Nene breeding habitat. 'Elepaio 54: 73-78

Sweeney JR, Sweeney JM and Sweeney SW (2003) Feral hog. In Feldhamer GA, Thompson BC and Chapman JA (eds). Wild Mammals of North America, 
The John Hopkins University Press, Baltimore, Maryland, United States 1164-1179

Sugimura K, Yamada F, Miyamoto A. (2005) Population trend, habitat change and conservation of the unique wildlife species on Amami Island, Japan. Global Environmental Research 6: 79-89

Telfair RC (1994) Cattle egret. In Poole A, Stettenheim P, Gill F (eds) The Birds of North America. The Academy of Natural Sciences of Philadelphia, Philadelphia, United States 1-32

Tomich PQ (1986) Mammals of Hawaii. Second Edition, Bishop Museum Press, Honolulu, Hawaii, United States

Towns, DR, Atkinson IAE, Daugherty CH (1990) Ecological restoration of New Zealand islands. Papers presented at conference on ecological restoration of New Zealand islands 1998. Department of Conservation, Wellington, New Zealand

UH (University of Hawaii at Manoa) (2006) Coqui Frog Control for Homeowners. Miscellaneous Pests MP-5. University of Hawaii at Manoa, College of Tropical Agriculture and Human Resources, Office of Communication Services, Honolulu, Hawaii.

USFWS (United States Fish and Wildlife Service) (1999) Draft Revised Recovery Plan for Hawaiian Waterbirds, Second Revision. United States Fish and Wildlife Service, Portland, Oregon, 107 pp

Van't Woudt BD (1990) Roaming, stray, and feral domestic cats and dogs as wildlife problems. Proceedings of Vertebrate Pest Conference 14: 291-295.

Vargas J, Landaeta C, Simonetti JA (2002) Bats as prey of barn owls in a tropical savanna in Bolivia. Journal of Raptor Research 36: 146-148

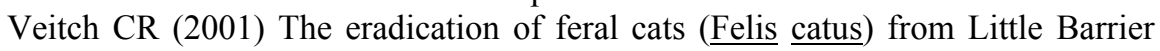
Island, New Zealand. New Zealand Journal of Zoology 28: 1-12

Veitch CR, Clout MN (eds) (2002) Turning the tide: the eradication of invasive species. Invasive Species Specialist Group, Species Survival Commission, World Conservation Union, Gland, Switzerland

Vice DS, Pitzler ME (2002) Brown treesnake control: economy of scales. Clark L (ed) Human conflicts with wildlife: economic considerations. National Wildlife Research Center, Fort Collins, Colorado, United States 127- 131

Vice DS, RM Engeman, Vice DL (2005) A comparison of three trap designs for capturing brown treesnakes on Guam. Wildlife Research 32: 355-359

Vilella FJ (1998) Biology of mongoose (Herpestes javanicus) in a rain forest in Puerto Rico. Biotropica 30: 120-125

Vitousek PM, D’Antonio CM, Loope LL, Westbrooks R (1996) Biological invasions as global environmental change. American Scientist 84: 468-47

Warner RD (1984) Occurrence and impact of zoonoses in pet dogs and cats at United States Air Force bases. American Journal of Public Health 74, 12391243

Wiewandt TA (1977) Ecology, behavior, and management of the Mona Island ground iguana, Cyclura stejnegeri. Ph.D. Dissertation, Cornell University, Ithaca, New York. United States 
Whittaker RJ (1998) Island biogeography: ecology, evolution and conservation. Oxford University Press, Oxford, United Kingdom

Williamson I (1999) Competition between the larvae of the introduced cane toad Bufo

marinus (Anura : Bufonidae) and native anurans from the Darling Downs area of southern Queensland. Australian Journal of Ecology 24: 636-643

Witmer GW, Lewis JC (2001) Introduced wildlife of Oregon and Washington. In Johnson D, O'Neil T (eds) Wildlife-habitat relationships in Oregon and Washington. Oregon State University Press, Corvallis, Oregon, United States 423-443

Witmer GW, Sanders RB and Taft AC (2003) Feral swine---are they a disease threat to livestock in the United States? Proceedings of the Wildlife Damage Management Conference 10: 316-325

Witte F, Goldschmidt T, Goudswaard PC, Ligtvoet W, van Oijen MJP, Wanink, JH (1992) Species extinction and concomitant ecological changes in Lake Victoria. Netherlands Journal of Zoology 42: 214-232

Wood B, Tershy BR, Hermosillo MA, Donlan CJ, Sanchez JA, Keitt BS, Croll DA, Howald GR, Biavaschi N (2002) Removing cats from islands in northwest Mexico. Veitch C, Clout M (eds) Turning the tide: the eradication of invasive species. World Conservation Union (IUCN), Gland, Switzerland 374-380 